ISSN:1308-8173

Geliş Tarihi: 03.06.2020
E-ISSN: 1308-8505

Kabul Tarihi: 12.07.2021
YIL: 2021

Online Yayın: 05.08.2021
Cilt: 36 Sayı: 2 Sayfa: $275-294$

Doi: 10.24988 /ije.202136203

\title{
E-Devlet Uygulamalarının Getirdiği Yenilik Algısının Kamu Çalışanlarında Sinizm Davranışlarına Etkisi: Sosyal Güvenlik Kurumu Çalışanları Üzerine Bir Araştırma \\ Hakan ÇAYALAN ${ }^{1}$, Uğur SADİoĞLU ${ }^{2}$ \\ Özet
}

Günümüz teknolojisinin getirdiği hızlı dönüşümler bireylere, örgütlere ve topluma değişim için baskı yapmaktadır. Bu hızlı dönüşüme ayak uydurma noktasında kuşak farkı göze çarpmaktadır. Kamu sektörü de teknolojinin sağladığı bu imkânlardan faydalanmaya çalışmaktadır. Bu reformların oluşturduğu etkilerin ölçülebilmesi için en önemli adımlardan biri söz konusu reformların zihinlerde oluşturduğu yenilik algısının ölçülmesidir. Nicel yöntemin anket tekniği ile veriler toplanmıștır. Yeniliklerin kurum personeli nezdinde ne ölçüde etki ettiğini, bu etkinin kamu personelinin örgütsel sinizm davranışlarına yansımalarını ortaya koymak adına geliştirilen "yenilik algısı ölçeği" ile çalışmaya uyarlanan "örgütsel sinizm ölçeği" Sosyal Güvenlik Kurumu (SGK) kamu personeline yüz yüze uygulanmıștır. Bu araştırmada ölçüm yapmak üzere e-Devlet uygulamalarının oluşturduğu yenilik algısı tercih edilmiş̧tir. SGK'nın seçilme sebebi ise e-Devlet uygulamaları içinde en çok kullanılan uygulamanın SGK uygulamalarından 4 A Hizmet dökümü uygulamasının olmasıdır. Örgütsel sinizm en basit tanımıyla çalışanların değişime karşı ve kuruma karşı kalıplaşan alaycı, tepkili, olumsuz tutumlarıdır. Örgütlerde yașanan bu köklü dönüșümlerin örgütsel sinizm olgusuna da etkisinin olacağı öngörülmüștür. Toplanan veriler bu öngörüyü desteklemiş, çalışanların yenilik algısının örgütsel sinizm üzerinde anlamlı bir etkiye sahip olduğu ortaya koyulmuştur. Ayrıca bu değişkenlerin demografik verilere bağlı farklılıkları da sorgulanmıștır. Kadın ve erkeklerin yenilik algılarının ve örgütsel sinizm düzeylerinin anlamlı farklılık gösterdiği, yaş, mesleki kıdem ve eğitim durumuna göre söz konusu değişkenlerin anlamlı farklılıklar gösterdiği sonuçlarına ulaşılmıștır. Ayrıca bölgesel karșılaștırmada yenilik algısının farklllık göstermediği ama örgütsel sinizm düzeyinin anlaml farklllıklar arz ettiği sonucuna ulaşılmıştır.

Anahtar kelimeler: e-Devlet, Sosyal Güvenlik Kurumu, Örgütsel Davranış, Yenilik Algısl, Sinizm

Jel Kodu: D23, M19, M14

\section{The Effect of Innovation of Perception Brought by e-Government Applications on Cynicism Behaviors of Public Employees: A Study on Social Security Institution Employees} Abstract

Rapid transformations brought about by today's technology put pressure on individuals, organizations and society for change. At this point of adaptation to the rapid transformation, the progeny difference is significant. The public sector is also trying to take advantage of these opportunities provided by technology. One of the most important steps to measure the effects of these reforms is to measure the perception of innovation about aforementioned reform in the minds of people. Data were collected by questionnaire technique of the quantitative method. The "innovation perception scale" that has developed to reveal to what extent these reforms affect the staff of the institution, and "organizational cynicism scale" that adapted to study have been applied to the public personnel of the Social Security Institution face to face for understand the reflections of this effect on the organizational cynicism. In this study, the perception of innovation created by e-government applications was preferred to measure. The reason for choosing SSI is that the most used application among E-government applications is the application of 4 A Service Scheme, one of the SSI applications. Organizational cynicism, in its simplest definition, is the cynical, reactive and negative attitudes of employees against change and towards the institution. It is predicted that these radical transformations in organizations will have an effect on the phenomenon of organizational cynicism. The collected data has been revealed that the employees' perception of innovation has a significant effect on organizational cynicism. In addition, the differences of these variables due to demographic data were also questioned. It was concluded that the perceptions of innovation and organizational cynicism of women and men differ significantly, and that these variables differ significantly according to age, professional seniority and educational background. In addition, it is concluded that the perception of innovation does not differ by region, but the level of organizational cynicism presents significant differences by region.

Keywords: E-Government, Social Security Institution, Organisational Behaviour, Perception of Innovation, Cynicism. Jel Codes: D23, M19, M14

ATIF ÖNERISİ(APA): Çayalan, H., Sadioğlu, U. (2021). E-Devlet Uygulamalarının Getirdiği Yenilik Algısının Kamu Çalışanlarında Sinizm Davranışlarına Etkisi: Sosyal Güvenlik Kurumu Çalışanları Üzerine Bir Araştırma. İzmir İktisat Dergisi, 36(2), 275-294.

Doi: 10.24988/ije.202136203

1 Öğr. Gör, Iğdır Üniversitesi, Tuzluca MYO, IĞDIR, EMAIL: hakancayalan@gmail.com ORCID: 0000-0002-8333-2638

${ }^{2}$ Doç. Dr., Hacettepe Üniversitesi, İIBF, Siyaset Bilimi ve Kamu Yönetimi Bölümü, Çankaya / ANKARA, EMAIL:ugursadi@hacettepe.edu.tr ORCID: 0000-0002-2454-4163 


\section{GíRiş}

Değişim ve yenilik kavramları, özellikle içinde bulunduğumuz çağda oldukça sık kullanılan kavramlardandır. Yenilikler her zaman kolaylıkla kabullenilmez veya istenen değişimler hızlı bir şekilde gerçekleştirilememektedir. Değişime bazen direnilmekte, bazen de değişim ertelenmektedir. Örgütlerin çevrelerindeki değişime karşı uyum geliştirmesini engelleyen ya da eylemsizliğine sebep olan içsel ve dışsal baskılar vardır. Örgütleri değişim karşısında engelleyici bu faktörler yapısal atalete ve eylemsizliğe neden olur (Leblebici, 2005: 4). Değişim süreci uzadıkça veya değişim ertelendikçe örgütlerin çevreyle uyumu azalmaktadır. Nihayetinde değişmek zorunda kalan örgütlerde çalışanlar, kalıplaşan uzun soluklu alışkanlıklarını ve davranışlarını değiştirmek istemez ve değişime direniş gösterirler. Değişimin radikalliği ve çalışanların direnci genellikle doğru orantılıdır. Kurt Lewin (1946) kuvvet alan analizi modelinde değişimin gerçekleşme düzeyinin değişime zorlayan güçler ile karşı koyucu güçlerin dirençleri arasında bir değer alacağını ortaya koymuştur. Değişim alışkanlığı olmayan ve değişime kendisini hazırlamamış olan çalışanlardan yoğun tepkiler çıkabilir. Örgütsel değișimde başarı personel direncinin kırılması ve değişime destekleriyle artırılabilir (Tunçer, 2013).

Bilgi çağının getirdiği teknolojik imkânlar hayatımızın neredeyse her alanına etki ettiği gibi kamu sektöründe de varlığını hızla göstermektedir. Kamu kurumlarının hemen hemen hepsinde iş ve işlemler bilgi ve iletişim teknolojilerinin sağladığı imkânlarla daha hızlı şekilde yerine getirilebilmektedir (Sadioğlu ve Yıldız, 2007). Ayrıca, bilgi ve iletişim teknolojilerinin e-Devlet kavramı altında kamu yönetiminin yapısında, süreçlerinde ve hizmetlerinde yarattığı etki reform olarak değerlendirilebilir. $\mathrm{Bu}$ çalışma ile gerçekleștirilen kamusal reformların kurumsal ve toplumsal anlamda katkılarını ölçen ve başarı değerlendirmesi yapan araçların çeșitlendirilmesine katkı yapmak hedeflenmiştir.

Yenilik algısı olarak isimlendirilen kavramın benzer isimli yenilikçilik temelli kavramlarla karıştırılmaması gerekmektedir. Literatürde yenilik/yenilikçilik üzerine farklı bakış açılarıyla çeşitli çalışmalar bulunsa da şimdiye kadar yenilik algısı şeklinde; örgütlerdeki herhangi bir yeniliğin zihinlerde nasıl algılandığını ölçmeye yönelik bir çalışmaya ulaşılamamıştır. Somutlaştırmak gerekirse Covin ve Slevin (1989)'in yenilikçilik ölçeğinin girişimcilik temelli, yenilikçilik yönelimi ölçeğinde gerçekleștirilen değerlendirmede bu ölçeğin daha çok șirketin yenilikçiliğini sorgulamaya yönelik ifadeler içerdiği görülmüștür. Benzer şekilde Yıldız (2017)'a ait yenilikçilik algısı, yenilikçilik faaliyetleri ve yenilik stratejileri üzerine yüksek lisans tezinde turizm işletmelerindeki yöneticilerin farklı boyutlarda yenilik algıları ölçülmüştür. $\mathrm{Bu}$ çalışmanın ölçeği incelenmiş ve örgütün yenilikçilik düzeyine dair algıyı ölçmeye odaklandığı, örgütün gerçekleștirmiş olduğu spesifik bir yeniliğe yönelik uygulanamayacağı sonucuna varılmıştır. İncelemede dikkate alınan bir diğer yüksek lisans tezinde örgütsel yeniliğin iç girişimcilik ve alt faktörleri üzerindeki etkisi ortaya konulmaya çalışılmıştır (Çorum, 2018). $\mathrm{Bu}$ çalışma yeniliği örgütsel düzeyde ele almış, yeniliğe dair örgüt iklimini ölçmeye odaklanmıştır. Bir başka çalışmada nitel araştırma tekniği kullanılarak yenilik algısı ve uygulamaları ile bunların işletme performansı üzerindeki etkisi incelenmiștir (Çınar, 2017). Reformların personel nezdinde algı düzeyini ölçmeye yönelik bir çalışma olmadığı sonucuna ulaşılmıştır. Bu çalışmanın çıkış noktasında; eDevlet uygulamalarının getirdiği yenilik ve değişimlerin personel tarafından olumlu algılanmasının, değişimlere ön yargılı, sinizm diye tabir edilen örgütsel davranışın örgütlerdeki yansıması üzerinde baskılayıcı etkisi olacağı öngörüsü bulunmaktadır. Bu kapsamda köklü bir yenilik olan e-Devlet odaklı kamusal reformların yenilik algısını ölçmek hedeflenmiştir. 
Çalışma kurgusunda algısının ölçülmesinin istendiği bir yenilik hususunda karar kılmadan önce bu yeniliğin hangi kavram ile ilişkilendirebileceği düşünülmüş ve yenilik karşısında olumsuz bir tutum ya da alışkanlık olan örgütsel sinizm kavramına karar verilmiştir. Daha önce farklı birçok değişken ile ilişkilendirilmiş olan olumsuz örgütsel davranışlardan sinizm; örgütsel bağlılık (Yücel ve Çetinkaya, 2015; Okçu vd., 2015; Yavuz ve Bedük, 2016; Yıldız, 2013; Özgan vd., 2012; Altınöz vd. 2011), örgütsel adalet (Güzel ve Ayazlar, 2014; Efeoğlu ve İplik, 2011), örgütsel sessizlik (Nartgün ve Kartal, 2013; Karacaoğlu ve Küçükköylü, 2015; Kalay vd., 2014), personel güçlendirme, örgütsel sessizleşme (Polat vd., 2010), örgütsel özdeşleşme ve iş performansı (Akdemir vd., 2016; Kahya, 2013; Çakıcı ve Doğan, 2013; Şantaş vd., 2016) kavramları ve daha birçok farklı kavram ile ilişkilendirilmiştir. Yeniliğin algısı yükseldikçe değişime dair olumsuz kalıpların kırılacağı ve değişime direnme davranışı olarak tabir edilen sinik tutumların azalacağı öngörüsü ile çalışma yenilik algısı kavramının örgütsel sinizmin üzerindeki etkisini tespite yönelik kurgulanmıştır. Bürokratik kırtasiyeciliğin yoğun olduğu klasik kamu yönetiminin dönüşümünde köklü bir yenilik arz eden eDevlet uygulamalarının oluşturduğu yenilik algısının ölçülmesine karar verilmiştir. Cumhurbaşkanlığı Dijital Dönüşüm Dairesi'nin (2019) açıkladığı üzere Türkiye vatandaşlarının 2019 yılı içerisinde en çok kullandığı e-Devlet hizmeti Sosyal Güvenlik Kurumu(SGK) 4A Hizmet Dökümü olmuştur. En çok kullanılan uygulamanın kurumuna bağlı personel üzerinde gerçekleştirilecek e-Devlet kamusal reformunun yarattığı yenilik algısı ölçümünün daha anlamlı olacağı öngörüsüyle çalışma SGK personeli üzerine sınırlandırılmıştır.

Yaşanan dönüșümlerden hizmet alanlar kadar kamu hizmeti sunan kamu personeli de etkilenmektedir. Çalışma kapsamında toplanan verilerle gerçekleştirilen kamusal reformlarının oluşturduğu kamu personelinin yenilik algı düzeylerinin ölçülmesi; ayrıca bu algı düzeyinin yaş, cinsiyet, eğitim düzeyi ve mesleki kıdem gibi değişkenlerle ilişkisinin tespiti amaçlanmıştır. Örgütlerde reform ve değișim hareketlerine gerek inanç düzeyinde gerekse duygu ve davranıș boyutlarında alaycı, eleștirel ve tepkili tutumlar sergileyen sinik personelin örgütsel sinizm davranışlarının, gerçekleştirilen değişimlerin faydalarının hissedilmesi ile azalacağı öngörülmektedir. $\mathrm{Bu}$ noktadan hareketle çalışma kapsamında olumsuz örgütsel davranışlardan, kamu çalışanlarının örgütsel sinizm düzeyinin de ortaya konması amaçlanmıştır. Aynı demografik değişkenlerle, örgütsel sinizmin ilişkisinin tespiti de amaçlanmıştır. Son olarak yenilik algısının örgütsel sinizme etkisi de ortaya konulmaya çalışılmıştır. Çalışmanın temel amacı, kamu yönetiminde gerçekleștirilen e-Devlet reformlarının genel olarak işlerliğini görmek, idari yönlü bakış açısı üzerine gerçekleştirilen araştırmaları çeşitlendirmek ve kamu çalışanları üzerindeki yansımasını tespit etmektir.

Kavramsal çerçeve ana başlığında çalışmamızın değişkenleri; e-Devlet, yenilik algısı ve örgütsel sinizm kavramları açıklanmıştır. Yöntem ana başlığında çalışmanın dayandığı bilimsel yaklaşımlar ve uygulama araçları hakkında bilgi verilmiş ve çalışma hipotezlerine yer verilmiştir. Bulgular ve tartışma ana başlığında araștırma verilerinin analizleri ve hipotez testlerinin sonuçları paylaşılmıştır.

\section{KAVRAMSAL ÇERÇEVE}

\section{1 e-Devlet Kavramının İrdelenmesi}

Toplumda düzenin sağlanması ve korunması için kamunun ortak ihtiyaçlarına yönelik mal ve hizmetlerin üretildiği sistem kamu yönetimidir. 18. Yüzyıl ile ortaya çıkan milli iradeye dayalı ulus-devletlerle, diğer ismiyle modern devletlerle önemi artmaya başlayan kavramdır. Dar anlamda yasama, yürütme ve yargı fonksiyonlarının ayrıldığı devletlerde; yürütmeye bağlı kurum ve kuruluşlar ile bağlı oldukları yargı faaliyetlerini ifade etmektedir. Geniş anlamda ise yasama ve yargl fonksiyonlarına bağlı kamu kuruluşlarını da kapsamaktadır (Duran,1982). Özetle denebilir ki kamu yönetimi kamu hizmeti yürüten devlet 
organları, kamu kurum ve kuruluşları ile bunların faaliyetleridir.

Bilgi ve iletişim teknolojilerinde yaşanan hızlı dönüşüm, özellikle internetin yaygınlaşması hayatın her alanında birçok dönüşümü tetiklemiştir. $\mathrm{Bu}$ dönüşümlerle genel olarak kamu sektöründen beklentilerde değişmiştir. $\mathrm{Bu}$ değişim devlet yönetiminde e-Devlet anlayıșını başlatmıștır (Önal, 2020). E-Devlet sadece yapısal bir dönüşümü ifade etmemekte, bundan daha önemlisi kamu yönetimde karar verme, uygulama ve izleme süreçlerinde yeni bir yaklaşımı da temsil etmektedir. Bilgi ve iletişim teknolojilerinin sürekli güncellediği e-Devlet anlayıșı kurumlar arasında etkileşimi, işbirliğini ve uyumu, kamu hizmetlerinin etkin ve etkili sunumunu, kamu yönetiminde desantralizasyonu, şeffaflığı ve hesapverebilirliği sağlamayı hedeflemektedir (Yıldı, 2007: 650). Dolayısıyla e-Devlet kamu yönetiminde yapısal, mal ve hizmet geliștirmesunma süreçlerinde sağladığı kolaylıklardan ziyade kapsamlı bir yönetim paradigması değişimini de ifade etmektedir. Yukarıdaki yönetişim ilkelerine ek olarak devlet, sermaye, sivil toplum ve vatandaşlar arasında iletişimi ve katılımı sağlama potansiyeli ile siyasal bir dönüşüme de kapı aralamaktadır.

E-Devlet vatandaşlar ve işletmeler bazında devlet işlerine dair hizmetlerin elektronik araç ve tekniklerin uygulanmasıyla üretilmesidir. Bilgi toplumu ve içinde bulunduğumuz bilgi çağ kamu hizmetleri içinde büyük imkanlar sunmaktadır. Kamu hizmetlerinin sunumu, vatandaşlarca algılanması, etkileşim süreci ve yeni firsatların keşfi klasik devlet-vatandaş iletişimini de yeni bir boyuta taşıyacaktır. $\mathrm{Bu}$ bakış açısıyla e-Devlet yalnız teknolojik olanakların kullanımı olarak görülmemektedir (Boyacıoğlu, 2018: 23). E-Devlet uygulamaları ile vatandaşlar ya da kamu hizmeti alıcıları internet üzerinden bilgilerine ulaşabilmekte, bazı işlemlerini yapabilmektedirler. Ayrıca kamu kurumları da daha hızlı, etkin ve verimli hale getirilebilmektedir. Bilgiye ulaşım kolaylaşmakta, şeffaf yönetim sağlanmakta ve iş birliği, etkileşim maliyetleri düşmektedir.
E-Devlet, kavramı farklı bakış açılarıyla çeşitli anlamlarda tanımlanmıştır. Bazıları e-Devleti basitçe dijital devlet bilgileri veya müşterilerle dijital işlemlere katılmanın bir yolu olarak tanımlamaktadır. Diğerleri için e-Devlet, siyasi konular ve hükümetle ilgili bilgilerin sunulduğu bir web sitesinin oluşturulmasından ibarettir. EDevleti tanımlamanın ve kavramsallaştırmanın bu dar yolları, sunduğu firsat yelpazesini kısıtlamaktadır. Birçok e-Devlet girişiminin başarısız olmasının nedenlerinden biri, e-Devlet kavramının, süreçlerinin ve işlevlerinin dar tanımı ve yetersiz anlaşılmasıyla ilgilidir. EDevlet, başarılı bir strateji tasarlayıp uygulayabilmek için geniş bir tanım ve anlayış gerektiren çok boyutlu ve karmaşık bir kavramdır (Ndou, 2004: 3).

E-devletin karakterize ettiği dönüşüm alanları ise şu şekilde ifade edilmiştir;

1. Dönüşüm alanları (iç, dış, ilişkisel);

2. Kullanıcılar, müşteriler, aktörler ve bunların karşılıklı ilişkileri (vatandaşlar, işletmeler, devlet kuruluşları, çalışanlar);

3. e-Devlet uygulama alanları (e-hizmetler, edemokrasi, e-yönetim).

Birçok düşük performans ve başarısız örnekleriyle vatandaşların, yasama organlarının veya kuruluşların beklentilerini karşılamayan eDevlet uygulaması örneği vardır (Anthopoulos, Reddick, Giannakidou, \& Mavridis, 2016; Askim, Christensen, Fimreite, \& Laegreid, 2010; Holmes, 2005; Morgeson III \& Mithas, 2009; Moynihan \& Lavertu, 2012). Yeni teknolojiler, yenilikçi bilgi, yönetim ve iletişim yaklaşımları iyimserlik sağlıyor gibi görünse de yakın zamana kadar bilim insanları hala temkinli tutumlarını sürdürmeye devam etmektedirler. E-Devlet uygulamalarındaki başarısızlıkların dayandırıldığı noktalar ise; yeniliklerin karmaşıklığı ve yeniliğe karşı beslenen ön yarglar, siyasi baskı ve erken revizyonlar, örgütsel ataletin yarattığı çekme kuvveti, bilgi boşluğunun sonuçları olarak sıralanmıştır (Choi \& Chandler, 2020: 1-6).

Olumsuz e-Devlet uygulamaları bir tarafa özellikle gelişmiş ülkelerde daha ileri boyutta e- 
yönetişim kavramı üzerine yoğunlaşılmaktadır. "Devlet" ile "yönetişim" arasında önemli bir ayrım vardır. Yönetim, kurumun kendisidir, oysa yönetişim, zorunlu olarak resmi hükümetin elinde olmayan yönetim biçimlerini tanımlayan daha geniş bir kavramdır. Yönetişim ifadesiyle, bir grubun kolektif faaliyetlerini yönlendiren ve sinırlayan hem resmi hem de gayri resmi süreçleri ve kurumları kastedilmektedir. Hükümet, otorite ile hareket eden ve resmi yükümlülükler yaratan alt kümedir. Yönetişimin yalnızca hükümetler tarafından yürütülmesi gerekmemektedir. Özel sektör, dernekler, sivil toplum örgütleri (STK'lar) ve STK dernekleri kamusal yetkileri olmasa da çoğu zaman hükümet organları ile birlikte yönetişim oluşturmak için bu faaliyetlere katılırlar (Saxena, 2005: 499). Eski model e-Devlet verileri işleyerek kamu yönetiminin iç işleyişini otomatikleştiren bilgi teknolojisi olarak tanımlanırken; e-yönetişim verileri işleyerek ileten, dış yönetişim işleyişini destekleyen ve dönüștüren bilgi ve iletişim teknolojisi olarak tanımlanmakta ve üç temel unsura dayandırılmaktadır. Bunlar; e-Devletin yönetim süreçlerinin iyileştirilmesi, e-hizmetler ve e-vatandaşlık olgularıyla vatandaşları birbirine bağlaması ve e-toplum ile dış etkileşimler oluşturmasıdır. Başarılı bir eyönetişim oluşturabilmek için hükümetlerin dikkate alması gereken hususlar ise; iyi bir teknolojik altyapı kurularak, başarılı bir hazırlık stratejisinin geliştirilmesi ve görsel tasarımdaki eksikliklerin kapatılmasına yönelik çalışmalar olarak tarif edilmektedir (Heeks, 2001). EDevlet ve e-yönetişimin potansiyeline bakıldığında; etkili bir ara yüze sahip kullanışlı bir teknolojik altyapıyla kurgulanan sistem sayesinde e-Devlet, yalnızca çoğu kamu hizmetinin sunulma şeklini değil, devlet ile vatandaş arasındaki temel ilişkiyi de dönüștürebilmektedir. Ayrıca bilgi sağlanma, şikâyet ve soruların elektronik ortamda ele alınması, izin / ruhsat başvurularının elektronik ortamda işleme alınması, vergi, harç, ücretlerin elektronik ortamda ödenmesi gibi birçok firsatı barındırmaktadır (Davidson vd., 2005: 282). Böylece e-Devlet anlayış ve içeriğinin teknolojik gelişmelere uygun olarak genişlediği ve derinleştiği söylenebilir.

\subsection{Yenilik Algısı Kavramı}

Algılama, kişinin herhangi bir durumu olduğu haliyle kaydetmesi değil, bu durumu kendine göre yorumlamasıdır. Bireysel farklılıklar algılama farklılıklarını tetikler. Algılama ve nedensellik yükleme, kişilerarası ilişkileri etkilediğinden örgütsel davranışın en temel konularındandır (Can vd., 2015: 39).

Reform hareketleri 15. yüzyıl itibariyle daha iyiye yönelik değişme ve bu değişimle daha iyi koşullara erişmeyi hedeflemektedir. İnsanlığın tarihsel gelişiminin temelinde de bu çaba yer almaktadır. Bu koşulları iyileştirme çabası sürekli olarak bilim ve teknolojiyi ilerlemeye zorlamış büyük, küçük farklı kapsamlarda değişimler yaratmıştır. Değişim kavramı yenilik, reform gibi kavramların hepsini kapsamaktadır. Reform kavramı ise diğerlerine göre daha derin değişimler içermesi ve önceki olumsuzlukların tümünü ortadan kaldırmayı hedeflemesiyle ayrılmaktadır. Yaratıcılıkla sıklıkla karıștırılsa ve ikame kullanımlarla karşımıza çıksa da yenilik mevcut uygulamalarda niteliği artırmayı hedefleyen değişimleri kapsayan bir süreçtir.

Yenilik kavramı ilk defa Schumpeter tarafından "Ekonomik Gelişme Teorisi" adlı kitap ile literatüre kazandırılmıştır. Schumpeter (1934) yenilik kavramını ekonomik gelişmelerin merkezindeki bir kaynak olarak ele almış ve var olanın yeni kombinasyonlarının geliștirilmesi, bir iş sürecinin yeni yollarının aranması olarak tanımlamıştır.

Yenilik kavramına dair farklı tanımlarda; bir örgütteki farklı bilgi birikimine sahip insanların verimlik ve etkinliklerini arttırmak için ilk defa onlara olanak tanıyan yararlı bilgi (Drucker, 1985), fikirlerin kullanışlı ürün ve hizmete dönüştürülmesi (Hjalager, 2002: 465), bir problemle bağdaştırılarak çözüm fikrini uygulamaya dönüştüren faaliyet, süreç ve ürün (Ottenbacher ve Gnoth, 2005: 206), şirketler açısından bir rekabet aracı (Porter, 1990) olarak ele alınmıştır. 
Literatürde yenilik kavramı; ürün veya hizmet yeniliği, pazarlama yeniliği, süreç yeniliği ve organizasyonel yenilik şeklinde türlere ayrılmaktadır. Yenilikçilik kavramı ise bireysel ve grupsal yenilikçilik şeklinde iki grupta incelenebilir (Özçer, 2005: 53-55).

Yöneticilerin, yaratıcı fikirlerinin çalıştıkları kuruluşlar tarafından değer gördügünü hissetmeleri, yüksek yenilik perspektiflerini teşvik edebilmektedir. Borins (2001), yeniliğin problem çözmede örgütsel işbirliği sayesinde gerçekleştiğini ortaya koymuştur.

Yenilikçilik temelli kavramlar yeniliğe açıklığı, bir yenilik gerçekleştirme istek ve arzusunu ortaya koymayı hedefleyen ifadeler içermektedir. Yenilik algısı ise gerçekleşmiş bir yeniliğin farkındalığını vurgulayan bir kavramdır. Yenilik algısı yükseldikçe örgüt içi problemlerin çözümünde işbirliği artabilir.

Yenilik algısı hedef belirleme teorisine dayandırılarak kurgulanmıştır. Hedef belirleme teorisinin temel kavramı, bireyler örgütsel birimin hedeflerini anlayarak iş davranışlarını etkilerler, böylece fikirler, yenilikler ve düşünceler bireyin kendi vizyon ve misyonuna hakimiyeti doğrultusunda büyümeye devam eder (Gibson vd., 2011).

Yenilik algısının hedefinde herhangi bir yeniliğin çalışanlar nezdinde içselleştirilerek destek olunması veya örgütsel bağlılık, örgütsel özdeşleşme gibi olumlu örgütsel davranışlara katkı sağlaması bulunmaktadır. Yenilik algısının düşük olması gerçekleștirilmeye çalışılan yeniliğin başarı olasılığını olumsuz yönde etkileyebileceği gibi örgüt ikliminde bozulmalara, değişim çabasıyla oluşan belirsizlik ortamıyla çalışanlar arasında, çalışanlar ve örgüt arasında çatışmaların artmasına sebep olabilir.

Yenilik algısının düşüklüğüyle mücadele etmek için yeniliklerin önündeki engellerin anlaşılması; firmaların yenilikçi davranışlar izlemesini engelleyen konuların aydınlatılması ve politika yapımında kritik öneme sahiptir (D’Este vd. 2014; Pellegrino \& Savona, 2017).
Araștırmalar yenilikleri farklı türlere ayırmakta örgütlerin farklı yenilik türlerine göre ortaya çıkan farklı engellerle yüzleşmeleri gerektiğini ortaya koymaktadır. Genel olarak ortak yenilik engelleri; maliyet, finans, piyasa koşulları, bilgi ve yapılandırma farklılıklarının analizine dayandırılmaktadır. Ayrıca yenilik hareketleriyle sıklıkla uğraşan yapılarda öğrenme eğilimi yükseleceğinden yenilik algısının yükseleceği vurgulanmaktadır. Özellikle uluslararasılaşmanın örgütlerde öğrenme etkilerini teşvik ettiğini ve daha fazla uluslararasılaşmış firmaların yenilik engelleri aștığı tespit edilmiștir. Yenilik faaliyetleriyle uğraştıkça, karmaşık yeniliklerin üstesinden geldikçe örgütlerde ve çalışanlarda yenilik engellerine dair algının yükseleceği vurgulanmaktadır. (De Fuentes vd. 2018: 1286).

$\mathrm{Bu}$ çalışma kapsamında çalışanların yenilik algısı üzerinde cinsiyet, yaş, mesleki kıdem, eğitim düzeyi ve görev yapılan bölgenin farklılaşması gibi değişkenlerin farklılıkları ölçülmüștür.

\subsection{Sinizm Kavramı}

Sinizm kelime kökeni antik Yunan felsefesindeki kinik düşüncesine dayandırılmaktadır Kinik felsefesindeki bireyler sosyal ve ahlaki kuralları reddetmekte ve doğa kanunları çerçevesinde yaşamaktadırlar. Antisthenes ve Diogenes en önemli sinikler olarak tarif edilmişlerdir (Mantere ve Martinsuo, 2001). Sinik bireyler tarihsel süreçte çalıștıkları kurumları hor görmeleriyle ve mizahı mesleki amaçları doğrultusunda silah olarak kullanmalarıyla ele alınmışlardır (Dean, Brandes ve Dharwadkar, 1998). Günümüzde ise "otorite ve kurumlara karşı olumsuz ve güvensiz tutumlar" şeklinde kavramlaştırılmıştır (Arslan, 2012: 13)

Çok geniş boyutlu bir kavram olan sinizm; literatürde bireysel ve örgütsel sinizm boyutlarında ele alınmıştır. Örgütsel sinizm; örgütün bütünlüğüne dair olumsuz inanç, örgüte dair negatif duygular ve örgüte karşı aşağılayıcı ve eleştirel davranış eğilimlerine dayanan olumsuz bir tutumdur (Dean vd. 1998: 345). Bir başka tanımda ise örgütsel sinizm çalışanların örgütün almış olduğu karar ve 
politikalara karşı takındıkları karamsar ve güvensiz düşünceleridir (Kosa, 2019: 365). Tüm farklılık gösteren tanımlamalara rağmen literatürde ortak görüş örgütsel sinizmin sabit kișisel bir özellik olmadığı, öğrenilmiş bir tutum, davranış ya da inanç olduğu yönündedir. Sinik olmak bir karar değildir, örgütsel sinizm deneyimlerle ortaya çıkmaktadır (Brown ve Gregan, 2008: 669). Örgütsel sinik kişi; örgütte problemlerin tespite açık olmasına rağmen sistemin eksik doğasından dolayı değişim, düzenleme, geliştirme çabasının boșa olduğuna inanmaktadır (McClough vd., 1998: 32). Birleşik devletlerde gerçekleştirilen çalışmalar işgücünün 1991 yılında \%48'inin sinik tutumda olduğunu saptamış (Kanter ve Mirvis, 1991: 50), 2004 yılında gerçekleştirilen bir başka çalışma, bu rakamın daha da artarak \%50'den fazla olduğunu ortaya koymuştur (Hochwarter vd. 2004).

Örgütsel sinizm türleri şunlardır (Kosa, 2019: 370-371):

Kişisel sinizm: Bireyin doğasında bulunur ve insan davranışlarını genellikle olumsuz olarak görür ve yorumlar.

İş gören sinizmi: Örgüt içindeki hemen hemen herkesi hedef alan sinizmdir.

Mesleki sinizm: Yapılan işin sıkıcılı̆̆ından, tatminden uzaklığından ve gösterilen çabaya değmeyeceği inancından kaynaklanan sinizmdir.

Toplumsal sinizm: Kișinin istek ve arzularının toplumca karşılanmamasından kaynaklı zamanla kişide gelișen sinizm algısıdır.

Örgütsel değişim sinizmi: Örgütlerde gerçekleşen başarısız değişimler sonucu çalışanlarda oluşan tepkilerle ortaya çıkan sinizmdir.

Örgütsel sinizmin nedenleri genel olarak çalışanların beklentilerinin ve deneyimlerinin uyumsuzluğu, iş ortamında yaşanan aldatılma, verilen sözlerin tutulmaması gibi olaylara bağlanmaktadır. Zamanla örgütsel sinizm çalışanlarda birçok olumsuz davranışı tetikleyerek örgüt iklimini de olumsuz etkilemektedir. Sinik olan çalışanlar, örgütle işbirliği ve uyumdan uzaklaşarak değişim çabalarını da sabote edebilirler.

Çalışma kapsamında örgütsel sinizmin üzerinde cinsiyet, yaş, mesleki kıdem, eğitim düzeyi ve görev yapılan bölgenin farklılaşması gibi değişkenlerin farklılıkları ölçülmüş, ayrıca yenilik algısı ile örgütsel sinizm ilişkilendirilmiş ve gerçekleştirilen analizler neticesinde yenilik algısından anlamlı şekilde örgütsel sinizmi etkilendiği tespit edilmiştir.

\section{YÖNTEM}

Çalışmada nicel araştırma yöntemi esas alınmıştır. Veri toplama aracı olarak anket tekniği belirlenmiștir. Kökleri Comte'un "kişisellikten uzak oluşum" ve "varlıklar ya da güçler" terimleri ile açıklanan pozitivist yaklaşımda davranışı anlama araçları gözlem ve akıldır (Balcl, 2015: 9). Anti pozitivist (Yorumcu) paradigma yaklaşımı ise pozitivizmin nesnellik görüşüne, insan davranışının ancak onun referans çevresini paylaşan araştırmacl tarafından anlaşllabileceğini ileri sürerek karşı çıkmaktadır (Balcı,2015: 29). Morgan, Onwuegbuzie ve Leech ise sosyal ve psikolojik araştırmalara yeni bir yön vermek üzere faydacı yaklaşımı önermektedir (Gliner vd. 2015: 9). Çalışma her ne kadar pozitivist yöntemlerle gerçekleştirilen bir alan araştırması olsa da yorumsamacı bir bakış açısıyla, uygulama esnasında edinilen gözlemler ve personelin kurumlarına dair verdiği bilgiler de dikkate alınmıştır. Çalışma ön kurgusuna en uygun örgütsel yenilik algısını ölçmeye yönelik ölçek arayışı için gerçekleştirilen literatür taraması sonucunda; kurumların, örgütlerin ya da organizasyonların gerçekleştirdikleri yeniliklerin tüketicileri konumundaki çalıșanları, personeli veya üyelerinin bu yenilikleri algı düzeylerini ölçmeye yönelik bir ölçeğin bulunmadığı gözlenmiştir. Bu ihtiyacı karşılamaya yönelik bir ölçek geliştirmek için bir soru havuzu oluşturulmuş ve oluşturulan bu soru havuzundaki sorular alanında uzman akademisyenlerin fikirleri alınarak sınırlanmıştır. Bu sınırlama neticesinde teste ilk 


\section{H. ÇAYALAN, U. SADIOĞLU}

şekli verilerek pilot uygulama gerçekleştirilmiştir.

Kass ve Tinsley (1979) sağlıklı analiz yapılabilmesi için toplamda minimum üç yüz kişiye ulaşılmasını veya ölçekteki madde sayısının asgari beș katı büyüklükte örneklem belirlenmesini hatta daha da sağlıklı analiz için on katı bireye ulaşılmasını tavsiye etmiştir. $\mathrm{Bu}$ sebeple pilot uygulamamız kapsamında ölçeğin kararlılığını gözlemlemek için test-tekrar test yöntemi kapsamında farklı zamanlarda öncelikle akademik ortamda otuz akademisyenden oluşan bir gruba ölçek yeni uygulanmaya başlanan bir uygulama üzerinden uyarlanarak uygulanmış ve dönüşlerin analizinde tatmin edici, anlamlı korelasyon değerleri elde edilmiştir. Bununla da yetinilmemiş tutarlılığını ölçmek adına ayrıca özel sektör çalışanlarından belirlenen otuz kişi üzerinde de uyarlanarak denenmiş; geçerliliği ve güvenilirliği sınanmıștır. Ölçeğin duyarlılık hassasiyeti için uygulamaya destek veren akademisyenlerden ölçeğin amaca uygunluğu noktasında geri dönüş yapmaları da istenmiş ve olumlu geri dönüşlerin yanında yapıcı tavsiyelerde dikkate alınmıştır. Pilot uygulama neticesinde eş zaman geçerliliğine sahip olduğu gözlemlenmiştir. $\mathrm{Bu}$ şekilde teste son şekli verilerek bu çalışmanın örneklemine göre uyarlanmıștır.

$\mathrm{Bu}$ akademik çalışma kapsamında yapı geçerliliğini test etmek için gerçekleştirilen açımlayıcı faktör analizinde de anlamlı sonuçlar elde edilmiştir. Analiz bölümünde faktör yük dağılımları mevcut olup çalışmanın KMO değeri .701 değeri ile anlamlıdır. İç tutarlılık güvenilirlik testlerinde çlkan cronhbach alfa .84 değeri ölçeğin güvenilirliğini ortaya koymaktadır.

Çalışma kapsamında uygulanan yenilik algısı ölçeğinin yanında ayrıca Güzeller ve Kalağan (2008) tarafından Türkçe'ye uyarlanan, Vance, Brooks ve Tesluk (1997) tarafından geliştirilen, geliştirme sürecinde .84 iç tutarlılık katsayısına sahip, dokuz soruluk örgütsel sinizm ölçeği çalışmaya uyarlanmıștır. (Treadway ve ark., 2004; Stanley, 1998; Tesluk ve ark., 1999).
Yenilik algısının ölçümünde klasik kamu yönetimi anlayışında gerçekleștirilen dijital dönüşümün öncülerinden e-Devlet kapısı seçilmiştir. E-Devlet kapısı sitesinin ana sayfasında en çok kullanılan hizmetler başlığında SGK'ya ait 4A Hizmet Dökümü uygulamasının 1.sırada yer alması ve Cumhurbaşkanlığı Dijital Dönüşüm Ofisi'nin (2019) 2019 yılı e-Devlet kullanımına dair açıklamaları esas alınarak çalışma SGK personeli üzerine sınırlandırılmıștır. SGK çalışanları çalışmanın toplam evreni olarak belirlenmiştir. Yeterli ve dengeli örnekleme ulaşabilmek ve bölgesel bir değerlendirme gerçekleştirebilmek adına Türkiye'nin batısından ve doğusundan kolayda örnekleme yöntemiyle şehirler seçilerek çalışma ölçekleri uygulanmıştır. Batıdaki Aydın ilindeki SGK personel sayısının daha fazla olmasından dolayı bölgesel karşılaştırma analizlerinde sağlıklı veriler elde etmek amacıyla doğu bölgesi için araştırma kapsamı Kars ve Iğdır şehirleri SGK personeli olarak belirlenmiştir. Bu şekilde çalışmanın hedef evreni 225 olarak tespit edilmiştir.

Çalışma kapsamında hazırlanan anket formu Iğdır, Kars ve Aydın illerindeki SGK İl Müdürlüklerinde görevli 216 kamu personeline uygulanmıştır. Uygulamanın gerçekleştirildiği illerde kurum il müdürlerine çalışma tanıtımı yapılarak, gerekli izinler alınmıș ve birebir kamu personeline ölçekler uygulanmıştır.

Ölçekler 5'li likert tipinde, "1. Hiç Katılmıyorum, 2. Katılmiyorum, 3. Kismen Katılıyorum, 4. Katılıyorum, 5. Tamamen Katılıyorum" şeklinde katılımcılara yönlendirilmiştir.

Araştırma verileriyle test edilmek üzere on bir adet hipotez geliștirilmiștir. Bunlar;

H1: SGK çalışanları erkekler ve kadınların yenilik algısı arasında farklılık vardır.

H2: SGK çalışanları erkekler ve kadınların örgütsel sinizm tutumları arasında farklılık vardır.

H3: SGK çalışanlarının yenilik algısı yaşlarına göre farklılık göstermektedir. 
H4: SGK çalışanlarının örgütsel sinizm tutumları yaşlarına göre farklılık göstermektedir.

H5: SGK çalışanlarının yenilik algısı mesleki kıdemlerine göre farklılık göstermektedir.

H6: SGK çalışanlarının örgütsel sinizm tutumları mesleki kıdemlerine göre farklılık göstermektedir.

H7: SGK çalışanlarının yenilik algısı eğitim durumlarına göre farklılık göstermektedir.

H8: SGK çalışanlarının örgütsel sinizm tutumları eğitim durumlarına göre farklılık göstermektedir.
H9: SGK çalışanlarının yenilik algısı görev bölgelerine göre farklılık göstermektedir.

H10: SGK çalışanlarının örgütsel sinizm tutumları görev bölgelerine göre farklılık göstermektedir.

H11: Yenilik algısı, örgütsel sinizmi anlamlı bir şekilde etkilemektedir.

\section{BULGULAR VE TARTIȘMA}

Öncelikle katılımclların cinsiyet, yaş, eğitim, medeni durum, mesleki kıdem gibi demografik özellikleri incelenmiş, ölçeklerin güvenilirliği test edilmiş ve daha sonra hipotezlerin test edilmesi aşamasına geçilmiştir.

Tablo 1: Katılımcıların demografik özelliklerine ilişkin sonuçlar

\begin{tabular}{|c|c|c|c|c|c|}
\hline \multicolumn{2}{|c|}{ Demografik veriler } & \multirow{2}{*}{$\frac{\text { Sıklık }}{140}$} & \multirow{2}{*}{$\frac{\text { Yüzde }}{64,8}$} & \multirow{2}{*}{$\frac{\text { Geçerli yüzde }}{64,8}$} & \multirow{2}{*}{$\frac{\text { Hesaplanan yüzde }}{64,8}$} \\
\hline Cinsiyet & Erkek & & & & \\
\hline & Kadın & 76 & 35,2 & 35,2 & 100,0 \\
\hline & Toplam & 216 & 100,0 & 100,0 & \\
\hline \multirow[t]{3}{*}{ Medeni Durum } & Evli & 164 & 75,9 & 75,9 & 75,9 \\
\hline & Bekar & 52 & 24,1 & 24,1 & 100,0 \\
\hline & Toplam & 216 & 100,0 & 100,0 & \\
\hline \multirow[t]{5}{*}{ Eğitim Durumu } & Ortaöğretim & 50 & 23,1 & 23,1 & 23,1 \\
\hline & Önlisans & 38 & 17,6 & 17,6 & 40,7 \\
\hline & Lisans & 106 & 49,1 & 49,1 & 89,8 \\
\hline & Lisans üstü & 22 & 10,2 & 10,2 & 100,0 \\
\hline & Toplam & 216 & 100,0 & 100,0 & \\
\hline \multirow[t]{9}{*}{ Yaş } & 21 yaș altı & 4 & 1,9 & 1,9 & 1,9 \\
\hline & $21-25$ yaş & 8 & 3,7 & 3,7 & 5,6 \\
\hline & $26-30$ yaș & 40 & 18,5 & 18,5 & 24,1 \\
\hline & $31-35$ yaș & 44 & 20,4 & 20,4 & 44,4 \\
\hline & $36-40$ yaş & 32 & 14,8 & 14,8 & 59,3 \\
\hline & $41-45$ yaș & 30 & 13,9 & 13,9 & 73,1 \\
\hline & $46-50$ yaș & 20 & 9,3 & 9,3 & 82,4 \\
\hline & 50 yaș üstü & 38 & 17,6 & 17,6 & 100,0 \\
\hline & Toplam & 216 & 100,0 & 100,0 & \\
\hline \multirow[t]{6}{*}{ Mesleki kıdem } & 1 yıldan az & 2 & 0,9 & 0,9 & 0,9 \\
\hline & $1-5 \mathrm{yll}$ & 64 & 29,6 & 29,6 & 30,6 \\
\hline & 6-10 yll & 60 & 27,8 & 27,8 & 58,3 \\
\hline & $11-15$ yll & 4 & 1,9 & 1,9 & 60,2 \\
\hline & 15 yıldan fazla & 86 & 39,8 & 39,8 & 100,0 \\
\hline & Toplam & 216 & 100,0 & 100,0 & \\
\hline Kurum Tercih & İdeal meslek & 10 & 4,6 & 4,6 & 4,6 \\
\hline \multirow[t]{5}{*}{ Sebebi } & Aile tavsiyesi & 2 & ,9 & ,9 & 5,6 \\
\hline & Puan yeterliliği & 62 & 28,7 & 28,7 & 34,3 \\
\hline & Olumlu Referanslar & 14 & 6,5 & 6,5 & 40,7 \\
\hline & Diğer & 128 & 59,3 & 59,3 & 100,0 \\
\hline & Toplam & 216 & 100,0 & 100,0 & \\
\hline \multirow[t]{4}{*}{ Bölgeler } & Iğdır & 50 & 23,1 & 23,1 & 23,1 \\
\hline & Kars & 54 & 25 & 25 & 48,1 \\
\hline & Aydın & 112 & 51,9 & 51,9 & 100,0 \\
\hline & Toplam & 216 & 100,0 & 100,0 & \\
\hline
\end{tabular}




\section{H. ÇAYALAN, U. SADIOĞLU}

Araștırma verilerinin analizinde SPSS22 programı kullanılmıştır. Öncelikle alınan frekans değerlerinin ardından ölçeklere faktör ve güvenilirlik analizleri uygulanmıştır. Ayrıca hipotezlerin testlerinde bağımsız örneklem ttesti, ANOVA ve regresyon analizinden faydalanılmıştır.

Tablo 1'de katılımcıların demografik bulguları yer almaktadır. Araştırmaya katılan Iğdır, Kars ve Aydın illerindeki SGK çalışanlarının \%64,8'ini erkekler, \%35,2'sini ise kadinlar oluşturmaktadır. \%75,9 gibi büyük bir oranı evli olanların oluşturduğu görülmektedir. $\mathrm{Bu}$ sebeple demografik veriler karşılaştırmalı analizlere dahil edilmiș olsa da medeni durumu bu kapsamın dışında bırakılmıştır. Katılımcıların yaş aralıklarını üçlü bir gruplandırmaya dahil edip; 30 yaş altını genç, 30-50 yaş aralığını orta yaş ve 50 yaş üstünü ileri yaş olarak sınıflandırıldığında, Çalışmaya katkı sağlayan SGK çalışanlarının \%58,3'ünün orta yaş grubu olduğu, genç grubun $\% 24,1$ ve ileri yaş grubunun \%17,6'llk bir kesimi ifade ettiği görülmektedir. Dolayısıyla kamu

Tablo 2. Açıklayıcı Faktör Analizi Sonuçları çalıșanlarının önemli bir kesiminin bilgi ve iletişim teknolojilerindeki ve e-Devlet uygulamalarındaki gelişmeleri deneyimlediği söylenebilir. $\mathrm{Bu}$ deneyim mevcut ve yeni teknolojilerin etkin ve etkili kullanımına olumlu yansıyacaktır.

Mesleki kıdem verileri kurumlarda sayısal nitelik anlamında en büyük grubun \%39,8'lik bir değer ile 15 yılı aşmış kamu personeli olduğunu ortaya koymaktadır. $\mathrm{Bu}$ durum çalışanların yaş düzeyleri ile uyum göstermektedir. E-Devlet uygulamalarına uyum ve yeni teknolojileri öğrenme açısından çalışan profili güçlü bir yan sergilemektedir. Bu özellik kurumsal kültür, kurumun özellikleri, kuruma özgü iş süreçleri açısından tamamlayıcı olumlu bir özellik olarak yorumlanabilir.

Kurum tercih sebebi verileri \%60 gibi büyük bir çoğunluğun diğer seçeneğine yoğunlaşması ve genel anlamda tercih sebeplerinin dengeli bir dağılım göstermemesinden dolayı değişkenlerle gerçekleştirilen farklılık analizlerine dahil edilmemiştir.

\begin{tabular}{|c|c|c|c|}
\hline \multicolumn{2}{|c|}{$\begin{array}{c}\text { Ölçek } \\
\text { önermeleri }\end{array}$} & \multirow{2}{*}{$\begin{array}{c}1 \\
.820\end{array}$} & \multirow[t]{2}{*}{2} \\
\hline YA 5 & E-Devlet uygulamaları kurum etkinliğini ve insan kaynağı verimliliğini arttırmıștır. & & \\
\hline YA 6 & $\begin{array}{l}\text { E-Devlet uygulamaları kurumdaki iş süreçlerini, insan kaynağının tutumlarını ve hizmet } \\
\text { kalitesini olumlu yönde geliștirmiștir. }\end{array}$ & .791 & \\
\hline YA 3 & E- Devlet uygulamaları ile hizmet alımı için kurumumuza gelenlerin sayısı azalmıștır. & .776 & \\
\hline YA 4 & E-Devlet uygulamalarının aktif kullanımı iş yükümüzü azaltmıştır. & .762 & \\
\hline YA 2 & E-Devlet Uygulamaları hayatımı çok kolaylaştırmaktadır. & .670 & \\
\hline YA 1 & E-Devlet uygulamalarını aktif şekilde kullanıyorum. & .654 & \\
\hline ÖS 3 & $\begin{array}{l}\text { Çalıştığım kurumda, insanların tutumu kötü olduğu için gelecekle ilgili umutlu olmak çok } \\
\text { zordur. }\end{array}$ & & .739 \\
\hline ÖS 5 & Çalıștığım kurumda, kișisel girișimler pek fazla önemsenmez. & & .737 \\
\hline ÖS 2 & Çalıștığım kurumu, geliștirmek için önerilerde bulunmayı bıraktım. & & .651 \\
\hline ÖS 4 & Çalıștığım kurumda, alıșılmıș șeyleri değiștirmek, getirilerinden çok sorunlara sebep olur & & .622 \\
\hline ÖS 9 & Çalıștığım kurumu, geliştirmek için yaptığım çabalar bilinir. & & .512 \\
\hline ÖS 6 & Çalıștığım kurumda, kamu personeli yapmadıkları iş için hak etmedikleri itibarı görürler. & & .506 \\
\hline ÖS 8 & Çalıștığım kurumda, önemli olan kimi tanıdığın değil, neyi bildiğindir. & & .474 \\
\hline ÖS 1 & Çalıștığım kurumda, pek çok insan ișlerin daha iyiye gideceğine inanır. & & .424 \\
\hline ÖS 7 & $\begin{array}{l}\text { Çalıștığım kurumda, kamu personeli iyi işler yapmak için ellerinden gelen çabayı sarf ettiklerine } \\
\text { güvenebilirsiniz. }\end{array}$ & & .322 \\
\hline \multicolumn{2}{|c|}{ Cronbach's Alpha Katsayısı } & .844 & .738 \\
\hline \multicolumn{2}{|c|}{ Açıklanan Varyans (\%) } & 26.99 & 16.62 \\
\hline \multicolumn{2}{|c|}{ Açıklanan Toplam Varyans (\%) } & \multicolumn{2}{|c|}{43.61} \\
\hline \multicolumn{4}{|c|}{ KMO $=.701$, Bartlett's Test of Sphericity $=3906.88(105), p<0.001}$. \\
\hline \multicolumn{4}{|c|}{ YA: Yenilik Algısı; ÖS: Örgütsel Sinizm } \\
\hline
\end{tabular}


Araştırma katılımcılarının eğitim durumuna bakıldığında, katılımcıların \%50'ye yakını üniversite mezunu ve \%10'a yakını ise lisansüstü düzeyde eğitim almıștır. Diğer eğitim düzeyi mezunları da birlikte değerlendirildiğinde, SGK çalışanları içerisinde önemli düzeyde kamusal reformlara, bilgi ve iletişim teknolojilerindeki gelişmelere uyumlu çalışan profili olduğu söylenebilir. Dolayısıyla eğitim düzeyi ve teknolojik gelişmelere açık olma gibi bir varsayım kamu çalışanlarının sinizm davranışlarını azaltacağı varsayımını güçlendirmektedir.

Bölgesel katılımcı sayıları değerlendirmesinde ise nüfusa bağlı iş yoğunluğu farkından kaynaklı olarak Aydın ilinden çalışmaya katkı veren SGK çalıșanlarının sayısının \%51,9'luk değer ile \%23,1'lik Iğdır ve \%25'lik Kars ili SGK personeline göre ağırlıkta olduğu görülmektedir.

Gerçekleştirilen faktör analizi sonucu ulaşılan .70 KMO değeri veri setinin analize uygunluğunu ortaya koymaktadır (Hair vd., 2010). İki faktörlü çalışmamızın faktör yüklerinin anlamlı dağılım gösterdikleri sonucu elde edilmiştir. Ölçeklere ait güvenilirlik sonuçlarını gösteren Cronbach (1951) alpha sonuçlarının $\quad .70$ sınırının üzerinde içsel tutarlılık koşulunu sağlamaları gözetilmektedir. Çalışmanın değişkenlerine ait cronbach alpha düzeyleri; yenilik algısı $a=.844$, örgütsel sinizm $a=.738$ 'dir (Tablo 2).

Tablo 3. Değişkenlere yönelik tanımlayıcı istatistikler, korelasyon düzeyleri

\begin{tabular}{ccccccc}
\hline Değişkenler & Ort. & Skewness & Kurtosis & Std. Sapma & YA & ÖS \\
\hline YA & 3.2314 & -.129 & -.493 & 0.037 & 1 & \\
ÖS & 3.1670 & 0.85 & 0.206 & 0.029 & $0.226^{*}$ & 1 \\
\hline
\end{tabular}

** Korelasyon 0.01 düzeyinde anlamlı. ${ }^{*}$ Korelasyon 0.05 düzeyinde anlamlı.

YA: Yenilik Algısı; ÖS: Örgütsel Sinizm

Faktörlerin normal dağılım gösterip göstermediklerinin ölçümü için KolmogorovSmirnov normal dağılım testi gerçekleştirilmiş ve $\quad \mathrm{p}>0.05$ anlamlılık düzeyinde gözlemlenmiştir. Ayrıca Skewness- Kurtosis değerlerinin +1 ve -1 aralığında yer alması da verilerin normalliğini ortaya koymaktadır (Hair vd., 2013). Değişkenler arası birlikte değişim ölçümü için Pearson korelasyon analizi sonuçları da tablo 3'te sunulmuştur.

Tablo 4. Yenilik Algısı ve Örgütsel Sinizmin Cinsiyet ile bağlantılı Bağımsız Örneklem T test sonuçları

\begin{tabular}{cccccc} 
& Cinsiyet & Frekans & Ortalama & Std. Sap. & P \\
\hline H1: Yenilik Algısı & Erkek & 140 & 3,2978 & 1,03906 &, 05137 \\
& Kadın & 76 & 3,1151 &, 78562 &, 05143 \\
\hline $\begin{array}{c}\text { H2: Örgütsel } \\
\text { Sinizm }\end{array}$ & Erkek & 140 & 3,1391 &, 78523 &, 03882 \\
& Kadın & 76 & 3,2159 &, 64465 &, 04220 \\
\hline
\end{tabular}

Çalışma hipotezlerinden $\mathrm{H} 1$ ve $\mathrm{H} 2$ hipotezlerinin test edildiği bağımsız örneklem t-test analizi neticesinde $\mathrm{H} 1$ hipotezi kabul edilmiş (F:9.862, t: 2,332, r: 0,020, P: 0.002) yenilik algısının cinsiyete bağlı olarak anlamlı bir farklılık gösterdiği tespit edilmiştir.
Örgütsel sinizmin ise cinsiyete bağlı olarak anlamlı bir farklılık göstermediği görülmüștür (F:3.454, t: $-1.270, \mathrm{r}: 0,205, \mathbf{P}: \mathbf{0 . 0 6 4}$ ) ve $\mathrm{H} 2$ hipotezi reddedilmiştir. Tablo 4'te elde edilen analiz sonuçları erkek çalışanların yenilik algısının kadınlara göre daha yüksek olduğunu 


\section{H. ÇAYALAN, U. SADIOĞ $L U$}

ortaya koymaktadır. Ayrıca kadın çalıșanların erkeklere göre örgütsel sinizm eğiliminin daha yüksek olduğu elde edilen ortalamalar neticesinde gözlemlenmiştir.

Tablo 5. Yenilik Algısı ve Örgütsel Sinizmin Yaşa göre Tek Yönlü Varyans Analizi Sonuçları

\begin{tabular}{|c|c|c|c|c|c|}
\hline & Yaș & Frekans & Ortalama & Std. Sap. & $\mathbf{P}$ \\
\hline \multirow{8}{*}{ H1: Yenilik Algısı } & 21 yaș altı & 4 & 2,3281 & 17277 & 04581 \\
\hline & 21-25 yaş & 8 & 2,8410 & ,54582 & 11090 \\
\hline & $26-30$ yaş & 40 & 3,6664 & ,67204 & ,06084 \\
\hline & 31-35 yaş & 44 & 3,3958 & ,97566 & 09007 \\
\hline & 36-40 yaș & 32 & 3,5689 & 1,12631 & 11576, \\
\hline & 41-45 yaş & 30 & 3,0653 & ,83424 & ,08984 \\
\hline & 46-50 yaș & 20 & 3,1389 & ,88854 & 11224 \\
\hline & 50 yaș üstü & 38 & 2,7205 & ,92418 & ,08398 \\
\hline \multirow{8}{*}{$\begin{array}{l}\text { H2: Örgütsel } \\
\text { Sinizm }\end{array}$} & 21 yaş altı & 4 & 3,5590 & ,11518 & 03054 \\
\hline & 21-25 yaş & 8 & 3,1325 & ,54617 & 11097, \\
\hline & 26-30 yaș & 40 & 3,1821 & ,59245 & 05364 \\
\hline & $31-35$ yaş & 44 & 2,8401 & ,65356 & ,06034 \\
\hline & $36-40$ yaş & 32 & 3,2144 & ,87299 & ,08972 \\
\hline & 41-45 yaş & 30 & 3,0991 & ,77271 & ,08322 \\
\hline & 46-50 yaş & 20 & 3,2317 & ,51424 & ,06496 \\
\hline & 50 yaș üstü & 38 & 3,4069 & ,85883 & ,07804 \\
\hline
\end{tabular}

Yukarıda yer alan tablo 5'te ise diğer demografik verilerden yaşa bağlı olarak örgütsel sinizm ve yenilik algısı kavramlarının farklılık gösterip göstermediğini dair analiz sonuçları yer almaktadır. Yaş verileri ile ANOVA testine tabi tutulan yenilik algısı verilerinin anlamlı bir farklılık gösterdikleri ortaya konmuş (F:15.668, P: 0.000) ve H3 hipotezi doğrulanmıştır. Aynı şekilde yaş gruplarının örgütsel sinizm düzeylerinin arasında da anlamlı bir farklılık gösterdikleri tespit edilerek (F:6.278, P: 0.000) H4 hipotezi de doğrulanmıştır. Ayrıca yaş gruplarının yenilik algısı değerlendirmesi için yaşın artmasıyla yeniliklere açıklık seviyesinin kademeli olarak azalacağına dair analiz öncesi beklentisi anlamını yitirmiştir. Sonuçlar en genç grubun yenilik algısının en alt seviyede olduğunu orta yaş grubunun yenilik algısının daha yüksek olduğunu ortaya koymuştur. Araştırma öncesi tasarım süreci öngörülerinde yaş ile doğru orantılı şekilde örgütsel sinizm seviyesinin artacağ yönünde olmasına rağmen, aynı dağılım örgütsel sinizm analiz sonuçlarına da yansımıştır.

Tablo 6. Yenilik Algısı ve Örgütsel Sinizmin Mesleki Kıdeme göre Tek Yönlü Varyans Analizi sonuçları

\begin{tabular}{cccccc}
\hline & Kıdem & Frekans & Ortalama & Std. Sap. & P \\
\hline & 1 ylldan az hizmet & 2 & 2,5000 &, 00000 &, 00000 \\
& $1-5$ ylllı hizmet & 64 & 3,5363 &, 82288 &, 05819 \\
H1: Yenilik Algısı & 6-10 ylllı hizmet & 60 & 3,3440 & 1,03867 &, 08234 \\
& $11-15$ ylllı hizmet & 4 & 3,5476 &, 97850 &, 32029 \\
& 15 ylldan fazla hizmet & 86 & 2,9438 &, 92633 &, 05668 \\
\hline H2: Örgütsel & 1 ylldan az hizmet & 2 & 3,4444 & 0,00000 & 0,00000 \\
Sinizm & $1-5$ ylllı hizmet & 64 & 3,2395 &, 57464 &, 04063 \\
& 6-10 ylllk hizmet & 60 & 2,8510 &, 73229 &, 05805 \\
& $11-15$ ylllk hizmet & 4 & 2,6720 &, 86978 &, 28470 \\
& 15 ylldan fazla hizmet & 86 & 3,3110 &, 79211 &, 04847 \\
\hline
\end{tabular}


Tablo 6'da yer alan veriler mesleki kıdem seviyelerine göre yenilik algısı ve örgütsel sinizm değerlerinin farklılı gösterip göstermediğine dair sonuçları yansıtmaktadır. Mesleki kıdem verileri ile ANOVA testine tabi tutulan yenilik algısı verileri anlamlı bir farklılık ortaya koymuş (F:13.912, P: 0.000) ve H5 hipotezi doğrulanmıștır. Aynı şekilde mesleki kıdem gruplarının örgütsel sinizm düzeylerinin arasında da anlamlı bir farklılık bulunduğu tespit edilerek (F:12.440, P: 0.000) H6 hipotezi de doğrulanmıştır. Mesleki kıdem seviyelerine ait frekansların ortalamalarının dağılımı yukarıda yaş değişkeninin ortaya koyduğu değerlerle paralellik göstermekte olup meslekte yeni olanlara ve mesleki kıdemleri en yüksek olanlara ait yenilik algısının daha düşük, örgütsel sinizm ortalamalarının daha yüksek seviyede olduğu, tecrübe olarak orta seviyede yer almakta olan grupların sonuçlarının ise tam tersi yenilik algılarının daha yüksek, örgütsel sinizm seviyelerinin ise daha düşük olduğu görülmüştür.

Tablo 7. Yenilik Algısı ve Örgütsel Sinizmin Eğitim Durumuna göre Tek Yönlü Varyans Analizi Sonuçları

\begin{tabular}{cccccc}
\hline & Eğitim & Frekans & Ortalama & Std. Sap. & P \\
\hline \multirow{3}{*}{ H1: Yenilik } & Ortaöğretim & 50 & 3,3826 &, 87424 &, 06975 \\
Algısı & Ön lisans & 38 & 3,0357 &, 98401 &, 08813 \\
& Lisans & 106 & 3,1676 &, 96289 &, 05533 \\
& Lisans üstü & 22 & 3,5769 &, 97080 &, 12772 \\
\hline \multirow{2}{*}{ H2: } & Ortaöğretim & 50 & 3,2046 &, 41821 &, 03337 \\
Örgütsel & Ön lisans & 38 & 3,4326 &, 76136 &, 06819 \\
Sinizm & Lisans & 106 & 3,1055 &, 80947 &, 04651 \\
& Lisans üstü & 22 & 2,8137 &, 78388 &, 10313 \\
\hline
\end{tabular}

Eğitim durumu değişkeni ile ANOVA testine tabi tutulan yenilik algısı verileri anlamlı bir farklılı̆̆ın varlığını ortaya koymuş (F:6.129, P: 0.000) ve H7 hipotezi doğrulanmıştır. Aynı şekilde eğitim seviyesi gruplarına göre örgütsel sinizm düzeylerinin arasında da anlamlı bir farklılık bulunduğu tespit edilerek (F:11.139, P: 0.000) H8 hipotezi de doğrulanmıştır. Eğitim seviyelerine ait frekansların ortalamalarının dağılımı eğitim seviyesi en düşük ve en yüksek olanların yenilik algısının, ön lisans ve lisans seviyesinde eğitim alanlara göre daha yüksek olduğu görülmüştür. Örgütsel sinizm ortalamalarında ise ön lisans mezunlarının örgütsel sinizm seviyelerinin en yüksek olduğu eğitim seviyesi bu kademeden itibaren arttıkça örgütsel sinizm seviyelerinin de düşüş göstermekte olduğu görülmüştür.

Tablo 8. Yenilik Algısı ve Örgütsel Sinizmin Bölgelere göre göre Tek Yönlü Varyans Analizi Sonuçları

\begin{tabular}{clcrrr} 
& Bölgeler & Frekans & Ortalama & Std. Sap. & \multicolumn{1}{c}{ P } \\
\hline \multirow{2}{*}{ H1: Yenilik } & Iğdır & 50 & 3,3128 & 1,04415 &, 08390 \\
Algısı & Kars & 54 & 3,1591 &, 94618 &, 07339 \\
& Aydın & 112 & 3,1993 &, 91612 &, 05111 \\
\hline \multirow{2}{*}{ H2: Örgütsel } & Iğdır & 50 & 3.0972 &, 84514 &, 06791 \\
Sinizm & Kars & 54 & 3,0781 &, 70768 &, 05489 \\
& Aydın & 112 & 2,8668 &, 67773 &, 03781 \\
\hline
\end{tabular}




\section{H. ÇAYALAN, U. SADIOĞ $L U$}

Yenilik algısı ve örgütsel sinizm değișkenlerinin bölgelere göre farklılıklarını gösteren tablo 8'e ait verilerde; görev bölgesi değişkeni ile ANOVA testine tabi tutulan yenilik algısı verilerinin anlamlı bir farklılık göstermediği ortaya koyulmuş (F:2.418, P: 0.090) ve H9 hipotezi reddedilmiştir. Görev bölgesi gruplarına göre örgütsel sinizm düzeylerinin anlamlı bir farklılık arz ettiği tespit edilerek (F:8.710, P: 0.000) H10 hipotezi de doğrulanmıştır. Bölgelere ait frekansların ortalamalarının dağılımı incelendiğinde Iğdır ilinin yenilik algısının Kars ve Aydın illerindeki kamu personeline göre daha yüksek olduğu, Kars ilinde çalışan personelin yenilik algısının bu üçlü sınıflandırmada en düşük seviyede kaldığı görülmektedir. Örgütsel sinizm açısından ise Aydın il SGK çalışanlarının örgütsel sinizm seviyelerinin kayda değer şekilde Iğdır ve Kars illerindeki meslektaşlarına göre daha düşük olduğu, Iğdır ilinde bu seviyenin en yüksekte bulunduğu görülmüştür. Sosyal yaşam ve iklim koşulları daha elverişli olan Aydın ilinde çalışan personelin sinik tutumlarının doğu illerindeki meslektaşlarına göre daha düşük olacağı yönündeki çalışma tasarımında öngörülen tahminlerin sonuçlarla uyuştuğu görülmektedir.

Tablo 9. Yenilik Algısının Örgütsel Sinizm Üzerindeki Etkisini Gösteren Regresyon Analizi Sonucu

\begin{tabular}{lccccccc}
\hline Bağımsız Değişken & $\mathrm{R}$ & $\mathrm{R} 2$ & Düzeltilmiș R2 & Beta & Standart Hata & $\mathrm{t}$ & $\mathrm{p}$ \\
\hline Yenilik Algısı & 0.226 & 0.051 & 0.050 & 0.226 & 0.030 & 5.879 & 0.000 \\
\hline Bağımlı Değișken: Örgütsel Sinizm & \multicolumn{1}{c}{} \\
\hline
\end{tabular}

Son olarak Tablo 9 ise yenilik algısının örgütsel sinizm üzerindeki etkisi görülmektedir. Gerçekleştirilen regresyon analizi sonucu yenilik algısının örgütsel sinizmi etkilediği tespit edilmiş ve H11 hipotezi de doğrulanmıștır. Bir örgütte gerçekleştirilen yeniliklerin olumlu algı seviyesi arttıkça değişime önyargılı sinik tutumların azalması beklentisi rasyonel olup; çalışma tasarlanırken gerçekleştirilen öngörüde de beklenti bu doğrultuda olmuştur. Yeniliklerin algısının yüksek olması demek bu yeniliklerin kurum personelince kullanılmakta olduğunu, hatta hizmet alıcılarının sayılarında bir azalmaya sebep olarak iş yükünü etkilediğini, değișimin iş ortamına olumlu yansımalarının çalışanlarca fark edildiğini ifade etmektedir. Yeniliklere dair yüksek algı düzeyi değişimin önünde örgütlerde set olmaya çalışan sinizm davranışlarıyla ilişkilendirilerek örgütsel sinizm üzerinde olumlu yönde bir etkiye sahip olduğu tespit edilmiştir.

Analizler sonucu elde edilen veriler ışığında H2 ve H9 hipotezleri reddedilmiş, diğer hipotezler doğrulanmıştır. Tablo $10^{\prime} \mathrm{da}$ hipotezlerin sonuçları bir araya getirilmiştir.

Tablo 10. Hipotez Test Sonuçları

\begin{tabular}{llc}
\hline H1: & SGK çalışanları erkekler ve kadınların yenilik algısı arasında farklılık vardır. & KABUL \\
H2: & SGK çalışanları erkekler ve kadınların örgütsel sinizm tutumları arasında farklılık vardır. & RED \\
H3: & SGK çalışanlarının yenilik algısı yaşlarına göre farklılık göstermektedir. & KABUL \\
H4: & SGK çalışanlarının örgütsel sinizm tutumları yaşlarına göre farklılık göstermektedir. & KABUL \\
H5: & SGK çalışanlarının yenilik algısı mesleki kıdemlerine göre farklılık göstermektedir. & KABUL \\
H6: & SGK çalışanlarının örgütsel sinizm tutumları mesleki kıdemlerine göre farklılık göstermektedir. & KABUL \\
H7: & SGK çalışanlarının yenilik algısı eğitim durumlarına göre farklılık göstermektedir. & KABUL \\
H8: & SGK çalışanlarının örgütsel sinizm tutumları eğitim durumlarına göre farklılık göstermektedir. & KABUL \\
H9: & SGK çalışanlarının yenilik algısı görev bölgelerine göre farklılık göstermektedir. & RED \\
H10: & SGK çalışanlarının örgütsel sinizm tutumları görev bölgelerine göre farklılık göstermektedir. & KABUL \\
H11: & Yenilik algısı, örgütsel sinizmi anlamlı bir şekilde etkilemektedir. & KABUL \\
\hline
\end{tabular}




\section{SONUÇ}

Bilgi çağıyla birlikte takibi güç bir hızla gelişmekte olan teknoloji bireyleri yenilikler konusunda kanıksayıcı ve umursamaz bir tutuma sürüklemektedir. Günümüz örgütlerinin gerek teknolojik gerekse sosyal dönüşümlere ayak uydurmak için gerçekleştirdikleri yeniliklerin başarısı, örgütlerin en önemli dişlilerinden olan insan kaynağınca bu yeniliklerin algilanmasına ve içselleștirilerek uygulanmasına bağlanabilir.

Yeniliğin son elli yılda köklü değişiklikler geçirdiğini yenilik tipolojilerini ve modellerini inceleyen bilim adamları ortaya koymuşlardır. $\mathrm{Bu}$ kapsamda bilim adamları yeniliğin beş kuşağı olduğunu ortaya koymuşlardır. Birinci ve ikinci kuşak doğrusal yeniliği kapsamakta proje odaklı kuşaklardır. Üçüncü kuşak geri dönüş ve etkileşim kavramalarının yenilik sürecindeki öneminin üzerinde durulması gerektiğini ortaya koymaktadır. Dördüncü kuşak ise takım çalışmasına vurgu yaparak, fikir ve bilginin başarısında tedarikçi ile müşterinin iletişim içinde olmasının önemini vurgulamaktadır. Beşinci kuşak ise yenilik modellerinin daha fazla esneklik, birbiriyle entegre, karmaşık ve çoklu ağlar oluşturması gerektiğini vurgulamaktadır (Hidalgo ve Alvano, 2014).

Yenilik algısını ölçmenin anlamını kavramak için Osmanlı Devleti'nin gerileme ve yıkılma sürecinde sürekli reformlar gerçekleştirmiş olmasına rağmen neden başarıya ulaşamadığı sorgulamak etkili olabilir. Belki o dönem kurumlarının çalışanları veya mensupları da yenilikleri yeterince algılasa ve içselleştirerek değişen koşullara uyumlu davransa veya sinik tutumlarla bu değişimlere direnmese tarih çok farklı bir senaryo üzerinde ilerlemiş olabilirdi.

İşte bu sebeple yenilik algısı kavramının gerek iç gerekse diş paydaşlar nezdinde örgütsel reformların, dönüşümlerin temel yapı taşı olduğu düşünülmektedir. Özellikle gelecekte gerçekleşebilecek potansiyel köklü dönüşümler için yenilik algısı kavramının ciddi bir potansiyel arz ettiği düşünülmektedir.
Çalışma verileri cinsiyete bağlı yenilik algısı verilerinde anlamlı farklılıklar olduğunu ortaya koymuştur. Erkeklerin kadınlara göre yenilik algılarının daha yüksek olduğu görülmüştür. Örgütsel sinizm davranışlarının cinsiyete bağlı farklılaşmadığı görülmüştür. Yaş değişkenine bağlı yenilik algısı ve örgütsel sinizmin farklılaşmakta olduğu görülmüştür. Genel sinıflandırma ile değerlendirilirse 50 yaş üstü yenilik algısının ortalamaya göre daha düşük, örgütsel sinizm ortalamalarının daha yüksek olduğu görülmüştür. Bu verilerde şaşırtıcı bir sonuç olmamakla birlikte 25 yaş altı kişilerin sonuçlarının da 50 yaş üstü kişilerin sonuçları ile paralellik göstermesi şaşırtıcıdır. 25 yaş altınında yenilik algısı düşük, örgütsel sinizm ortalamaları yüksek çıkmıştır. Orta yaş grubu ise ortalamanın üzerinde bir yenilik algısı ile düşük örgütsel sinizm ortalamaları göstermiştir. Bir sonraki adımda sırasıyla mesleki kıdem ve eğitim seviyesi ile bağlantılı farklılık gösterip göstermedikleri test edilen iki değişkenin anlamlı sonuçlar verdikleri tespit edilmiştir. Kıdem verileri yaş ile paralellik göstermiştir. Eğitim durumu verileri ise eğitim seviyesinin yükselmesiyle yenilik algısının arttığını, buna paralel örgütsel sinizm ortalamalarının azaldığını ortaya koymuştur. Değişkenler bölgesel olarak karşılaştırıldığında; yenilik algısının bölgelere göre anlamlı şekilde farklılaşmadığı gözlenmiștir. Örgütsel sinizmin ise bölgelere göre anlamlı olarak farklılaştı̆̆ı sonucuna ulaşılmıştır. Aydın ilinde çalışan SGK personelinin örgütsel sinizm seviyesinin Kars ve Iğdır illerindeki meslektaşlarına göre daha düşük olduğu gözlenmiştir.

Son olarak çalışma kurgusunda yeniliklerin işlerliğiyle yenilik algısının yükseleceği ve değişime dair kalıplaşmış ön yargıların kısmen dağılacağı bu sayede örgütsel sinizm düzeyinin etkileneceği öngörüsü H11 hipotezinin analizi ile doğrulanmıştır. Soru bazlı değerlendirmede göze çarpan kurumlarında e-Devlet uygulamaları sonrası iş yükünün azalmadığı yönünde fikir beyan eden kayda değer çoğunlukta bir kitle olması e-Devlet uygulamasından beklentilerinde yüksek 


\section{H. ÇAYALAN, U. SADIOĞ $L U$}

olduğunu ortaya koymaktadır. Her ne kadar eDevlet uygulamaları içinde en yoğun kullanılan uygulamalar SGK ile alakalı uygulamalar olsa da kurum personeli uygulama esnasında da şu ifadeyi yoğun şekilde dile getirmiştir: Vatandaşlar hâlâ e-Devlet kullanımı noktasında yeterince bilinçlenmemiş ve e-Devlet üzerinden kolaylıkla gerçekleştirebilecekleri işlemler içinde kuruma yoğun şekilde başvurmaktadır. $\mathrm{Bu}$ yüzden kurum personelinin bu tutumu muhafaza ettikleri düşünülebilir. Kamusal reformlara karşı bu denli yüksek beklenti değişimin getirilerine karşı bir kayıtsızlık olușturduğu gibi örgütsel sinizm tutumunu sürdürme eğilimini de değiştirmeyebilir. Bu konuda kesin bir şekilde yargıda bulunabilmek için vatandaşın e-Devlet algı düzeyini ölçmeye yönelik bir çalışma gerçekleștirilmelidir. Ayrıca SGK'nın işlem hacmine yönelik veriler talep edilerek, e-Devlet üzerinden gerçekleştirilen işlem hacmi ile karşılaștırılabilir. Bu şekilde kamu personelinin söylemi doğrulanarak daha bağlayıcı tespitler elde edilebilir. Bölgesel farklılıklara dair sonuçlarda yaşanılan bölgenin sosyal imkanlarının, iklim koşullarının etkili olabileceği gibi farklı birçok etkende farklı çalışmaların konusu olabilir.

Çalışma değişkenleri farklı sektörlerde, organizasyonlarda ve kurumlarda da tatbik edilerek elde edilecek sonuçlar karşılaştırılabilir. Ayrıca değişkenler farklı değişkenler ile ilişkilendirilerek akademik literatür çeşitlendirilebilir. Çalışma kapsamında geliştirilen hipotezler farklı örneklem üzerinden elde edilen veriler ışığında yeniden teste tabi tutulabilir. Çalışma verileri literatürün bakış açılarının çeşitlendirilmesi ve yeniliklerin başarısında örgütsel düzeyde ele alınması kadar personel nezdinde algısının da etkili olduğunu ortaya koyarak; sektörlerde yenilikçi kurumların farkındalığının arttırılmasına katkıda bulunacaktır. $\mathrm{Bu}$ çalışmanın sonuçlarının, çağdaş çalışma ortamlarının gerçeklerini yakalamak için, başkalarını kavramsal gelişimlerini genişletmeye teşvik etmesi umulmaktadır.

\section{KAYNAKÇA}

Altınöz, M., Çöp, S. ve Sığındı, T. (2011), Algılanan Örgütsel Bağlılık Ve Örgütsel Sinizm İlişskisi: Ankara'daki Dört Ve Beş Yıldızlı Konaklama İşletmeleri Üzerine Bir Araștırma. S.Ü. I.I.B.F Sosyal ve Ekonomik Araştırmalar Dergisi, 11(21), 285-316.

Akdemir, B., Kırmızıgül, B. ve Zengin, Y. (2016). Örgütsel Sinizm İle İş Performansı Arasındaki İlişki Ve Bir Araştırma, Kahramanmaraş Sütçü İmam Üniversitesi İktisadi ve İdari Bilimler Fakültesi Dergisi, 6(2), 115-130.

Anthopoulos, L., Reddick, C. G., Giannakidou, I. ve Mavridis, N. (2016). Why E-Government Projects Fail? An Analysis of The Healthcare. Gov Website. Government Information Quarterly, 33(1), 161-173.

Arslan, E. T. (2012). Süleyman Demirel Üniversitesi İktisadi Ve İdari Bilimler Fakültesi Akademik Personelinin Genel Ve Örgütsel
Sinizm Düzeyi. Doğuş Üniversitesi Dergisi, 13 (1) 2012, 12-27.

Askim, J., Christensen, T., Fimreite, A. L. ve Laegreid, P. (2010). How To Assess Administrative Reform? Investigating The Adoption And Preliminary Impacts of The Norwegian Welfare Administration Reform. Public Administration, 88(1), 232- 246.

Balcı, A. (2015). Sosyal Bilimlerde Araştırma Yöntem, Teknik ve İlkeler (11. Baskı), Ankara: Pegem Akademi.

Borins, S. (2001). Encouraging İnnovation İn The Public Sector. Journal of Intellectual Capital, 2(3), 310-319.

Boyacıoğlu, N. (2018). Türkiye'de E-Devlet Hizmetlerinin Eğitim Ve Sosyal Hayat Üzerindeki Etkileri, Journal of Internatıonal Socıal Sclences Academic Researches Dergisi, 2(1), 22-31. 
Brown, M. Ve Gregan, C. (2008). Cynicism: The Role Of Employee İnvolvement, Human Resource Management, 47, 667-686.

Can, H., Azizoğlu, Ö. A. ve Aydın, E. M. (2015). Örgütsel Davranış. Ankara: Siyasal Kitabevi.

Choi, T. ve Chandler, S. M. (2020). Knowledge Vacuum: An Organizational Learning Dynamic Of How e-Government Innovations Fail. Government Information Quarterly, 37(1), 101416.

Covin, J. G. ve Slevin, D. P. (1989). Strategic Management Of Small Firms İn Hostile And Begining Environments. Strategic Management Journal, 10, 75-87.

Cumhurbaşkanlığı Dijital Dönüşüm Ofisi (2019). "Dijital Türkiye Portaline 1.000.000.000 Giriş" 13 Kasım 2019 tarihli haber. (Erişim Tarihi: 01.01.2021) https://cbddo.gov.tr/haberler/4297/dijitalturkiye-portaline-1-000-000-000-giris

Çakıcı, A. ve Doğan, S. (2013). Örgütsel Sinizmin İş Performansına Etkisi: Meslek Yüksekokullarında Bir Araştırma. Doğuş Üniversitesi Dergisi, 15(1), 79-89.

Çınar, K. (2017). Otel İşletmelerinde Yenilik Algısı Ve Uygulamaları, Aksaray Üniversitesi Íktisadi ve İdari Bilimler Fakültesi Dergisi, 9 (2), 37-50.

Çorum, G. (2017). The Perception Of Innovation Effect On Intrapreneurship: A Study On Private Companies (Master's Thesis), İstanbul: Bahçeşehir Üniversitesi.

Davidson, R. M., Wagner, C. ve Ma, L. C. (2005). From Government To E-Government: A Transition Model, Information Technology \& People, 18(3), 280-299.

Dean Jr, J.W., Brandes, P. ve Dharwadkar, R. (1998). Organizational Cynicism. The Academy Of Management Review, 2 (23), 341-352.

D'este, P., Rentocchini, F. ve Vega-Jurado, J. (2014). The Role of Human Capital In Lowering The Barriers To Engaging In Innovation: Evidence From The Spanish
Innovation Survey, Industry And Innovation, 21(1), 1-19.

Duran, L. (1982). İdare Hukuku Ders Notları, İstanbul

Drucker, P. F. (1985). Entrepreneurial Strategies. California Management Review, 27(2), 9.

Efeoğlu, E. ve İplik E. (2011). Algılanan Örgütsel Adaletin Örgütsel Sinizm Üzerindeki Etkilerini Belirlemeye Yönelik İlaç Sektöründe Bir Uygulama. Çukurova Üniversitesi Sosyal Bilimler Enstitüsü Dergisi, 20 (3), 343-360.

Gibson, J.L., Ivancevich, J.M., Donnelly, Jr., J.H., ve Robert Konopaske, R. (2011). Organizations: Behavior, Structure, Processes (14th Ed.), Irwin, Usa: Mcgraw-Hill.

Gliner, J. A., Morgan, G. A. ve Leech, N. L. (2015). Uygulamada Araştırma Yöntemleri: Desen ve Analizi Bütünleştiren Yaklaşım (Çev. Ed: Selahattin Turan), Nobel Yayın Dağıtım, 2. Basımdan Çeviri, Ankara.

Güzel, B. ve Ayazlar, G. (2014). Örgütsel Adaletin Örgütsel Sinizm Ve İşten Ayrılma Niyetine Etkisi: Otel İşletmeleri Araştırması, Kmü Sosyal ve Ekonomik Araştırmalar Dergisi, 16 (26),133-142.

Güzeller C. Ve Kalapan G. (2008). Örgütsel Sinizm Ölçeğinin Türkçe'ye Uyarlanması Ve Çeşitli Değişkenler Açısından Eğitim Örgütlerinde İncelenmesi, 16. Ulusal Yönetim Ve Organizasyon Kongresi Bildiri Kitabı, 87-94.

Hair, J. F., Anderson, R. E., Babin, B. J. ve Black, W. C. (2010). Multivariate Data Analysis, A Global Perspective. 7, $\mathrm{Nj}$ : Pearson Upper Saddle River.

Hair, J. F., Black, W. C., Babın, B. J., Anderson, R. E. ve Tatham, R. L. (2013), Multivariate Data Analysis. Pearson Education Limited.

Hidalgo A. ve D’alvano L., (2014). Service Innovation: Inward And Outward Related Activities And Cooperation Model. Journal of Business Research, 67, 698-703.

Heeks, R. (2001). Understanding EGovernance For Development, i-Government 


\section{H. ÇAYALAN, U. SADIOĞLU}

Working Paper Series, (Erişim Tarihi: 28.12.2020).

https://papers.ssrn.com/sol3/papers.cfm?ab stract_id $=3540058$

Hjalager, A. M. (2002). Repairing Innovation Defectiveness In Tourism, Tourism Management. 23, 465-474.

Hochwarter, W.A., James, M., Johnson, D. ve Ferris, G.R. (2004). The Interactive Effects of Politics Perceptions And Trait Cynicism On Work Outcomes. Journal of Leadership and Organizational Studies, 10 (4), 45-57.

Holmes, D. (2005). Drop The "e": Marketing eGovernment To A Skeptical Public And Webweary Decision Makers, In M. KhosrowPour (Ed.). Practicing E- Government: A Global Perspective (Pp. 199-231). Hershey, Pa: Idea Group.

Kahya, C. (2013). Örgütsel Sinizm, İş Performansını Etkiler Mi? İş Tatminin Aracılık Etkisi. Global Journal of Economics and Business Studies, 2 (3) , 34-46.

Kalay, F., Oğrak, A. ve Nişancı, Z. N. (2014), Mobbing, Örgütsel Sessizlik Ve Örgütsel Sinizm İlişkisi: Örnek Bir Uygulama. Kastamonu Üniversitesi İktisadi ve Ídari Bilimler Fakültesi Dergisi, 4(2), 127-143.

Kanter, P.H. ve Mirvis, D.L. (1991). Beyond Demography: A Psychopraphic Profile of Workforce. Human Resource Management, 30 (1), 45-68.

Karacaoğlu, K. ve Küçükköylü C. (2015). İşgören Sessizliğinin Örgütsel Sinizme Etkisi: Kamu Çalışanları Üzerine Bir Araştırma. Ege Akademik Bakış, 15(3), 401-408.

Kass, R. A. ve Tinsley, H. E. A. (1979). Factoranalysis. Journal of Leisureresearch, 11(2), 120-138.

Kosa, G. (2019). Örgütsel Sinizm, E. Kaygın, G. Kosa (Ed.), Olumsuz Boyutlarıyla Örgütsel Davranış, Konya: Eğitim Yayınevi.

Leblebici, D. N. (2005). Küresel Değişim Baskısına Karşı Türk Bürokrasisindeki Yapısal Uyum Çabalarının Yapısal Atalet Kavramı
Açısından Değerlendirilmesi. C. Ü. Íktisadi ve İdari Bilimler Dergisi, 6(1), 1-14.

Lewin, K. (1946). Force Field Analysis. The 1973 Annual Handbook For Group Facilitators, 111-13.

Mantere,S. ve Martinsuo, M. (2001). Adopting and Questioning Strategy: Exploring The Roles of Cynicism and Dissent. Paper To Be Presented At 17th Egos, European Group for Organisation Studies, Colloquium, 5-7.

Mcclough, A.C., Rogelberg, S.G., Fisher, G.G. ve Bachiochi, P.D. (1998). Cynicism and The Quality of An İndividual's Contribution To An Organizational Diagnostic Survey. Organization Development Journal, 16 (2), 3142.

Morgeson, F. V., III, ve Mithas, S. (2009). Does E-Government Measure Up To E-Business? Comparing End User Perceptions of Us Federal Government And E- Business Web Sites, Public Administration Review, 69(4), 740-752.

Moynihan, D. P. ve Lavertu, S. (2012). Cognitive Biases In Governing: Technology Preferences In Election Administration, Public Administration Review, 72(1), 68-77.

Nartgün, S. S. ve Kartal, V. (2013), "Ögretmenlerin Örgütsel Sinizm Ve Örgütsel Sessizlik Hakkındaki Görüşleri”, Bartın Üniversitesi Eğitim Fakültesi Dergisi, 2(2), 4767.

Ndou, V. (2004). E-Government For Developing Countries: Opportunities And Challenges. The Electronic Journal of Information Systems In Developing Countries, 18(1), 1-24.

Okçu, V., Şahin, H. M. ve Şahin E. (2015). Beden Eğitimi Ve Spor Öğretmenlerinin Örgütsel Sinizme İlișkin Algılarının Örgütsel Bağlılıkları Üzerindeki Etkisi. Special Issue On The Proceedings Of The 4th Iscs Conference - Part B, August

Ottenbacher, M. ve Gnoth, J. (2005). How To Develop Successful Hospitality İnnovation. 
Cornell Hotel And Restaurant Administration Quarterly, 46(2), 205- 222.

Önal, M. F. (2020). E-Devlet Kapısı İstatistikleri Ve Değerlendirmeler, 4 Mart 2020 Tarihli Açık Erişim Makale.

(http://www.egovturkey.com/E-DevletKapisi-\%C4\%B0statistikleri-Ve-

Degerlendirmeler-04032020). Erişim Tarihi: 28.12.2020

Özçer, N. (2005). Yönetimde Yaratıcılık ve Yenilikçilik. İstanbul: Rota Yayınları.

Özgan, H. Külekçi, E. ve Özkan, M. (2012). Öğretim Elemanlarının Örgütsel Sinizm İle Örgütsel Bağlılık Düzeyleri Arasındaki İlişskinin İncelenmesi. International Online Journal of Educational Sciences, 4(1), 196-205.

Pellegrino, G., ve Savona, M. (2017). No Money, No Honey? Financial Versus Knowledge And Demand Constraints on Innovation. Research Policy, 46(2), 510-521.

Polat, M., Meydan, C. ve Tokmak, İ. (2010). Personel Güçlendirme, Örgütsel Özdeşleşme Ve Örgütsel Sinizm İlişkisi Üzerine Bir Araştırma, Kara Harp Okulu Bilim Dergisi, 20 (2).

Porter, M. E. (1990). The Competitive Advantage Of Nations, Free Press, New York.

Sadioğlu, U. ve Yıldız M. (2007). Kamu Yönetimi ile Bilgi ve İletişim Teknolojileri: Bir Bibliyografik Analiz, Hacettepe Üniversitesi Íktisadi ve İdari Bilimler Fakültesi Dergisi, 25(2), 323 -366.

Saxena, K. B. C. (2005). Towards Excellence İn E-Governance. International Journal of Public Sector Management, 18(6), 498-513.

Stanley, D.J. (1998). Employee Cynicism About Organizational Change: Development And Validation Of A Measure. (Unpublished Master Dissertation), Ontario: The University of Western Ontario.

Schumpeter, J. A. (1934). The Theory of Economic Development: An Inquiry Into Profits, Capital, Credit, Interest, And The Business Cycle, Transaction Publishers (2006).
Stanley, D.J., Meyer, J.P. ve Topolnytsky, L. (2005). Employee Cynicism And Resistance To Organizational Change, Journal of Business And Psychology, 19 (4), 429- 459.

Şahin,A. (2014), Türk Kamu Yönetiminde Yapısal Dönüşüm ve E-Devlet, İstanbul: Atlas Akademi Yay.

Şantaş, F., Uğurluoğlu, Ö., Kandemir, A. ve Çelik, Y. (2016). Sağlık Çalışanlarında Örgütsel Sinizm, İş Performansı Ve Örgütsel Özdeşleşme Düzeyleri Arasındaki İlişkilerin İncelenmesi. Gazi Üniversitesi Íktisadi Ve İdari Bilimler Fakültesi Dergisi, 18(3), 867.

Tesluk, P.E., Vance, R.J. ve Mathieu, J.E. (1999). Examining Employee Involvement In The Context of Participative Work Environments. Group Organization Management, 3 (24), 271299.

Treadway, D.C., Hochwarter, W.A., Ferris, G.R., Kacmar, C.J., Douglas, C., Ammeter, A.P. ve Buckley, M.R. (2004). Leader Political Skill And Employee Reactions. The Leadership Quarterly, 4 (15), 493-513.

Tunçer, P. (2011). Örgütsel Değişim ve Liderlik. Sayıştay Dergisi, 80(1), 57-83.

Turan, Ş. (2011). Küreselleșme Sürecinde Örgütsel Değişimi Etkileyen Bir Unsur Olarak Örgütsel Sinizm ve Karaman İli Kamu Kurumlarında Bir Uygulama, (Yüksek Lisans Tezi), Karaman: Karamanoğlu Mehmetbey Üniversitesi Sosyal Bilimler Enstitüsü.

Yavuz, A. ve Bedük A. (2016). Örgütsel Sinizm ve Örgütsel Bağlılık Arasındaki İlişki: Bir Kamu Bankasının Konya Şubelerinde Örnek Uygulama, Selçuk Üniversitesi Sosyal Bilimler Enstitüsü Dergisi, 35, 301-313.

Yıldız, K. (2013). Örgütsel Bağlılık İle Örgütsel Sinizm Ve Örgütsel Muhalefet Arasındaki İlişki, Turkish Studies - International Periodical For The Languages, Literature And History of Turkish Or Turkic, 8(6), 853-879.

Yıldız, M. (2007). E-government research: Reviewing the literature, limitations, and ways 
forward, Government Information Quarterly, 24, 646-665.

Yıldız, M. R. (2017). Turizm Isşletme Yöneticilerinin Yenilikçilik Algısının Yenilikçilik Faaliyetlerine Ve Yenilik Stratejilerine Etkisi: Bartın, Zonguldak ve Karabük Illerinde Bir Araştırma (Yüksek Lisans Tezi), Bartın: Bartın Üniversitesi, Sosyal Bilimler Enstitüsü.

Yücel, İ. ve Çetinkaya, B. (2015). Örgütsel Sinizm İle Örgütsel Bağlılık Arasındaki İlişki Ve Çalışanların Yaşının Bu İlişki Üzerindeki Etkisi'Bazen Hoşlanmasak Da Kalmak Zorunda Olabiliriz!',Journal Of Graduate School Of Social Sciences, 19(3), 247-271.

https://www.turkiye.gov.tr/ (Erişim Tarihi: 28.12.2020). 